\title{
Analýza průběhu dopravních nehod s virtuálním modelem člověka VIRTHUMAN
}

\author{
Pedestrian-to-vehicle Accident Analysis Using a Virtual Human Body Model \\ VIRTHUMAN
}

\author{
Luděk Kovářr ${ }^{*}$, Jana Hlucháa, Tomáš Novotnýb \\ ${ }^{a}$ MECAS ESI s.ro., Plzeñ \\ ${ }^{b} I N G-P A E D I G I P-M E C A S$ ESI s.r.o., Brno
}

\begin{abstract}
Abstrakt
Článek prezentuje virtuální model lidského těla VIRTHUMAN a možnosti jeho využití v simulacích dopravních nehod s účastí chodce. VIRTHUMAN je plně validovaný škálovatelný biomechanický model, založený na MBS struktuře, jež se skládá z tuhých segmentů vzájemně propojených klouby. Jedná se o víceúčelový model vhodný pro simulaci různých typů nárazů, včetně simulace komplikovaných situací s vícečetnými nárazy.

Jedním ze způsobů využití zmíněného modelu je simulace a vyhodnocení rizik srážek chodce $\mathrm{s}$ vozidlem, na jejichž následky každoročně umírá nezanedbatelné množství lidí. Společností MECAS ESI byl vytvořen software, jenž automatizuje nastavení konfigurace a následné vyhodnocení srážky chodce s vozidlem. V rámci konfiguračního procesu je možné nastavit řadu parametrů, které průběh a následky nehody ovlivňují, jako jsou antropometrické parametry chodce, jeho pozice vi̊či vozidlu, tvar př́iě vozidla a jeho rychlost $\mathrm{v}$ době nárazu.

Př́spěvek byl prezentován v rámci 27. mezinárodní vědecké konference Soudního inženýrství ExFoS 2018.
\end{abstract}

Klíčová slova: VIRTHUMAN, virtuální prototyp, model člověka, nehody $\mathrm{s}$ chodcem, náraz, VPS.

\section{1. ÚVOD}

V roce 2015 zemřelo v České republice při dopravních nehodách 131 chodců, což tvoří 19,8 \% všech úmrtí na silnicích. Dalších 554 chodců bylo v tomtéž roce vážně zraněno [1]. Přestože v celé Evropské Unii byla přijata řada opatření zvyšujících bezpečnost silničního provozu a počet obětí dopravních nehod klesá [1], jejich množství je stále alarmující. Velká pozornost je proto věnována vývoji pasivních i aktivních bezpečnostních systémů, díky nimž by se měl počet zraněných a usmrcených osob při nehodách i nadále snižovat.

V současnosti musí veškeré osobní automobily uváděné na trh splňovat př́islušné bezpečnostní normy, např. Evropské normy

\begin{abstract}
The aim of this paper is to present the virtual human body model VIRTHUMAN and the possibility of its usage in the prediction and consequences analysis of pedestrian-to-vehicle accident. The VIRTHUMAN model is a fully validated scalable biomechanical model which combines the multi-body structure with deformable segments. The model is multi-purpose, i.e. it is suitable for various crash scenarios, including the complex ones with multiple impacts.

Thanks to the multi-purpose nature, the model is suitable for wide spectrum of applications. A software tool was developed by MECAS ESI, which uses the VIRTHUMAN model for simulations of traffic accidents in which pedestrian is involved. In the software, it is possible to configure and evaluate a custom accident with several adjustable parameters, particularly the pedestrian age, height, and mass, its position in the moment of the crash, and the shape of the vehicle's frontal end.
\end{abstract}

The paper was presented on the $27^{\text {th }}$ International Scientific Conference of Forensic Engineering, ExFoS 2018.

Keywords: VIRTHUMAN, virtual prototype, human body model, pedestrian accident, crash, VPS.

ECE-R95, 96/27/EC pro boční nárazy nebo ECE-R94, 96/79/ EC pro čelní nárazy. Tyto normy jsou doplňovány takzvaným zákaznickým testováním vozidel, jakým jsou např́klad evropské testy EuroNCAP. Pro tato testování jsou využívány konkrétní schválené figuríny, např. WorldSID pro boční a Hybrid III pro čelní nárazy. Tyto figuríny však mají omezený způsob využití, nebot' jsou určeny jen pro konkrétní typ nárazu, jenž je daný instalovanými sensory a dalším hardwarem. Mimo to není možné je využít pro vyšetřování nehod chodců nebo přizpůsobit jejich tělesné rozměry a postihnout tak rozmanitost lidské populace.

I s ohledem na výše uvedená omezení jsou při vývoji aktivních i pasivních bezpečnostních systémů stále častěji využivány 
virtuální modely člověka. Tento článek se věnuje virtuálnímu modelu VIRTHUMAN vyvinutém pro výpočetní prostředí VPS PAM-CRASH společnosti ESI Group a možnostem jeho využití. VIRTHUMAN je plně validovaný [2], víceúčelový, škálovatelný model, tvořený MBS (multi-body-system) strukturou $\mathrm{s}$ deformovatelnými segmenty. Tento hybridní př́istup $\mathrm{v}$ sobě slučuje předvídatelnost deformovatelných modelů a nízkou výpočetní náročnost MBS modelů. Model je možné snadno škálovat na požadovaný věk, výšku a hmotnost a umístit jej do libovolné pozice, díky čemuž může být využit pro široké spektrum nárazových zkoušek - nejen jako pasažér libovolného dopravního prostředku, ale i jako chodec.

Závažnost poranění chodce při srážce s vozidlem je výrazně ovlivněna mimo jiné pozicí chodce vůči vozidlu v době srážky, jeho tělesnými rozměry nebo rychlostí jízdy a tvarem př́dě vozidla. Pro simulaci tohoto typu nehod byl vyvinut software, který umožňuje nakonfigurovat čelní srážku vozidla s chodcem $\mathrm{s}$ řadou nastavitelných parametrů chodce i vozidla. Pomocí implementovaného nástroje je možné vyhodnotit průběh nehody a stanovit pravděpodobná poranění jednotlivých částí těla v různých fázích nárazu a tyto výsledky pak porovnat pro různé scénáře nehody.

\section{VIRTHUMAN - VÍCEÚČELOVÝ MBS MODEL LIDSKÉHO TĚLA}

Kostra modelu VIRTHUMAN je tvořena soustavou tuhých těles, které reprezentují jednotlivé části lidského těla, vzájemně propojených klouby. Tyto klouby jsou charakterizovány nelineárními pružinami a tlumením ve všech stupních volnosti, což je nezbytné pro zachycení realistické odezvy lidského těla.

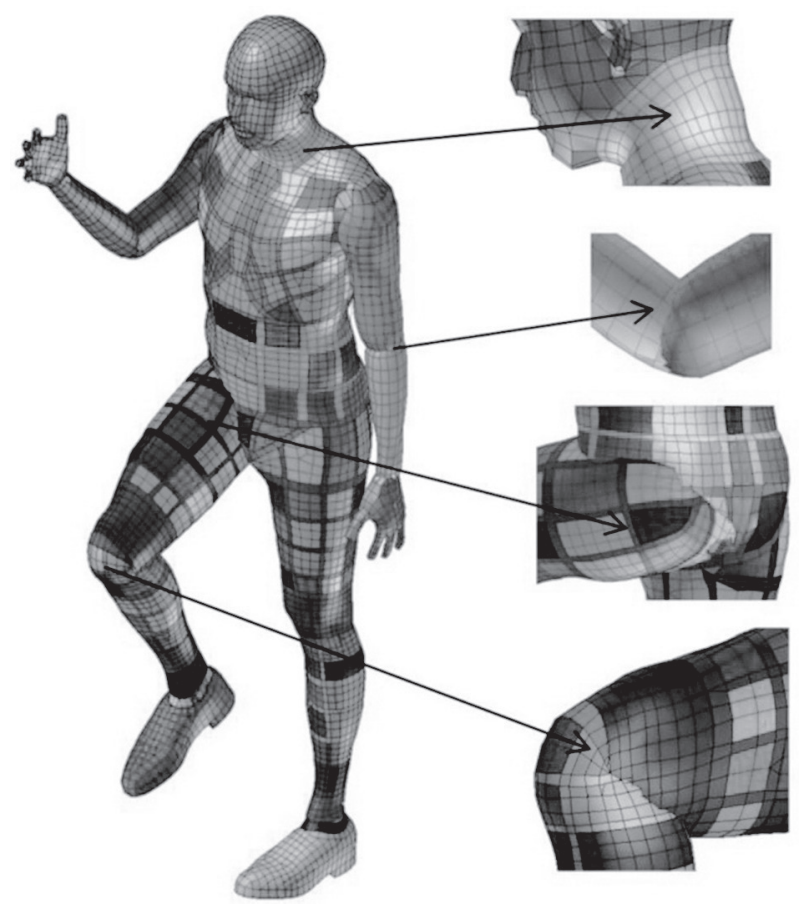

Obr. 1 Souvislý povrch modelu při ohybu kloubů. Fig. 1 Continuous surface of the articulated model.
Vnější povrch modelu sestává z tuhých segmentů vzájemně spojených pásy elementů bez mechanické rezistence. Tyto vnější segmenty jsou s kostrou MBS spojeny pomocí nelineárních posuvných kloubů napodobujících odezvu tkání. Povrch modelu je sít'ován tak, aby byla zachována jeho hladkost a spojitost i při změně pozice modelu, např. jeho posazení nebo nakročení, viz obr. 1.

Tělesné rozměry referenčního 50\% VIRTHUMAN modelu jsou odvozeny z hodnot z evropské antropometrické databáze CAESAR.

\section{1 Škálování modelu VIRTHUMAN}

Důležitou součástí modelu VIRTHUMAN je implementovaný škálovací algoritmus, který prostřednictvím uživatelského rozhraní umožní vygenerovat model požadovaného pohlaví, věku, výšky a hmotnosti. Škálování umožňuje postihnout rozmanitost lidské populace v oblasti tělesných rozměrů a může být využito např́iklad při testování srážek s chodci, kde zejména výška chodce významně ovlivňuje průběh nehody a míru jeho poranění. S modelem VIRTHUMAN je tak možné provést simulaci stejné nehody pro několik různě velkých a starých jedinců včetně dětí a sledovat vliv antropometrických parametrů chodce na získané výsledky.

\subsection{Validace modelu VIRTHUMAN}

Každá část těla 50\% modelu VIRTHUMAN i model jako celek byly validovány na základě dostupných experimentálních dat. Například při validaci hrudníku bylo provedeno několik různých validačních

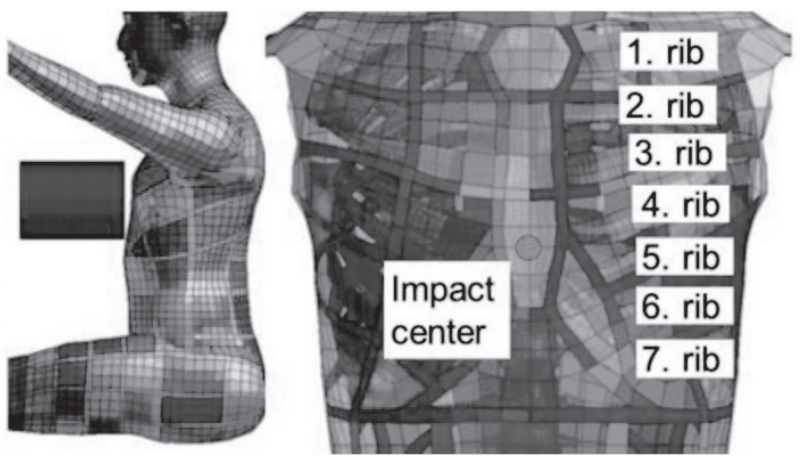

Obr. 2 Konfigurace testu podle Kroell a kol. Fig. 2 Test setup according to Kroell et al.

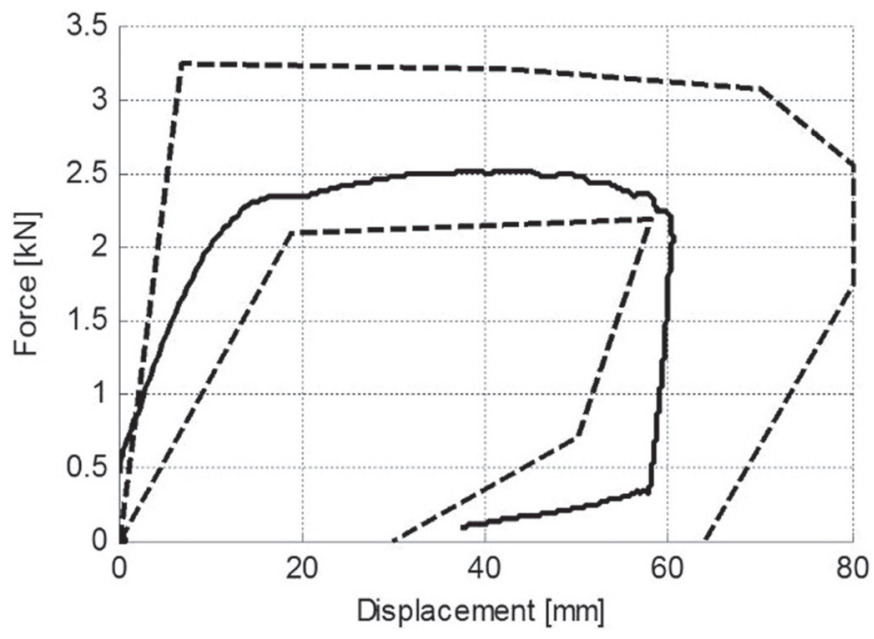

Obr. 3 Závislost kontaktni síly a posuvu hrudníku při rychlosti $4,9 \mathrm{~m} / \mathrm{s}$. Fig. 3 The deflection dependent impactor contact force at velocity of $4.9 \mathrm{~m} / \mathrm{s}$. 
testů pro různé typy a směry nárazu. Odezva na náraz zpředu je validována podle Kroell et al. [3][4], kdy válcový impaktor o hmotnosti 23,4 kg naráží do hrudníku rychlostmi 4,9 m/s, $6,7 \mathrm{~m} / \mathrm{s}$ a $9,9 \mathrm{~m} / \mathrm{s}$, přičemž validace probíhá na základě časového průběhu stlačení hrudníku a kontaktní síly mezi hrudníkem a impaktorem. Podle experimentu byl VIRTHUMAN umístěn do polohy vsedě se zdviženými pažemi (viz obr. 2). Výsledky validačních testů pro jednotlivé rychlosti nárazu, konkrétně křivky závislosti kontaktní síly a posuvy hrudníku, jsou uvedeny na obr. 3, obr. 4 a obr. 5 . Přerušovanou čarou je vymezený experimentálně stanovený koridor, plná čára značí výsledek simulace. Pro rychlosti 4,9 m/s a $6,7 \mathrm{~m} / \mathrm{s}$ prochází celé křivky ze simulace danými koridory; mimo koridor se nachází pouze část křivky $\mathrm{z}$ experimentu s rychlostí nárazu $9,9 \mathrm{~m} / \mathrm{s}$. Toto vybočení z koridoru není pro proces validace zásadní, nebot' energie při tomto nárazu je již neslučitelná se životem.

Odezva hrudníku na boční náraz je validována válcovým impaktorem o hmotnosti 23,4 kg, který naráží ze strany

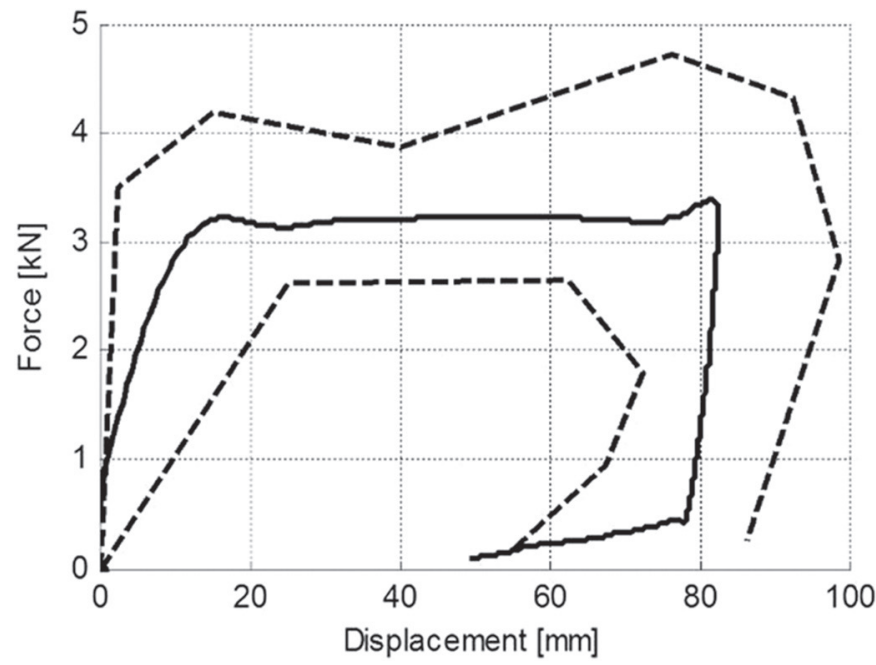

Obr. 4 Závislost kontaktní síly a posuvu hrudniku při rychlosti $6,7 \mathrm{~m} / \mathrm{s}$. Fig. 4 The deflection dependent impactor contact force at velocity of $6.7 \mathrm{~m} / \mathrm{s}$.

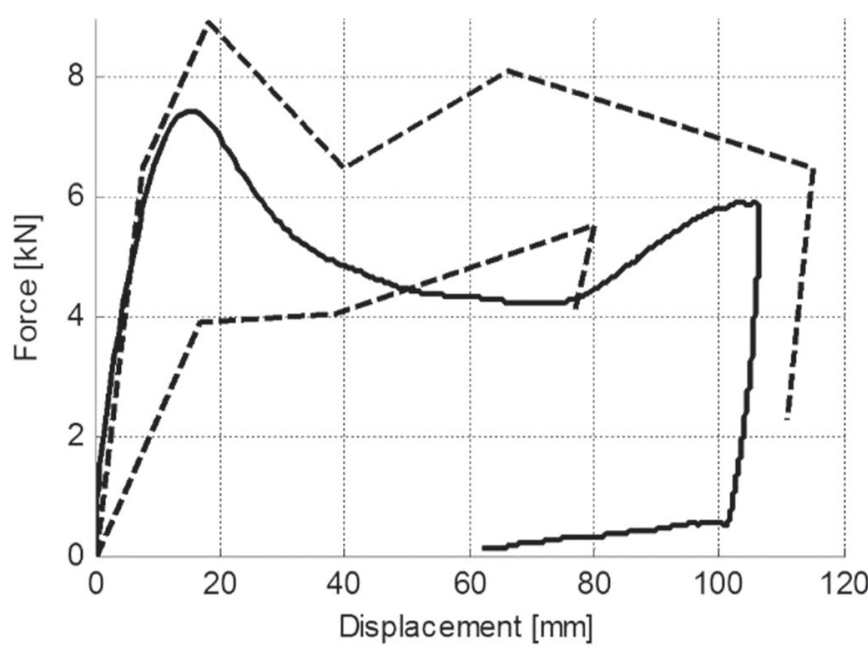

Obr. 5 Závislost kontaktní síly a posuvu hrudniku při rychlosti $9,9 \mathrm{~m} / \mathrm{s}$. Fig. 5 The deflection dependent impactor contact force at velocity of $9.9 \mathrm{~m} / \mathrm{s}$.

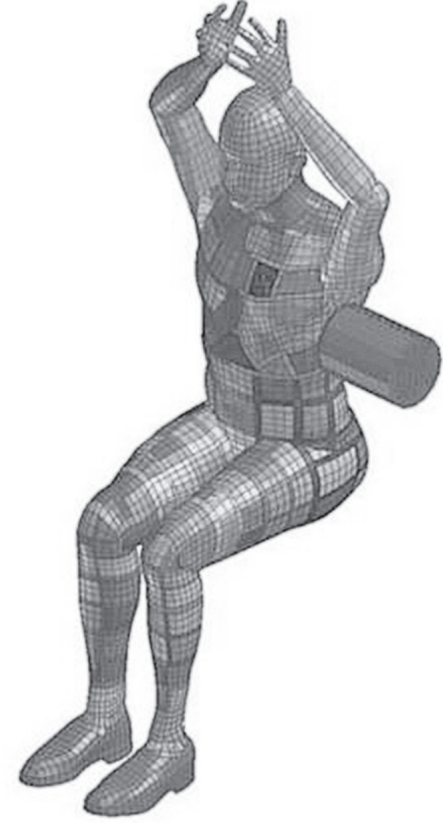

Obr. 6 Konfigurace HSRI testu.

Fig. 6 Test setup of the HSRI test.

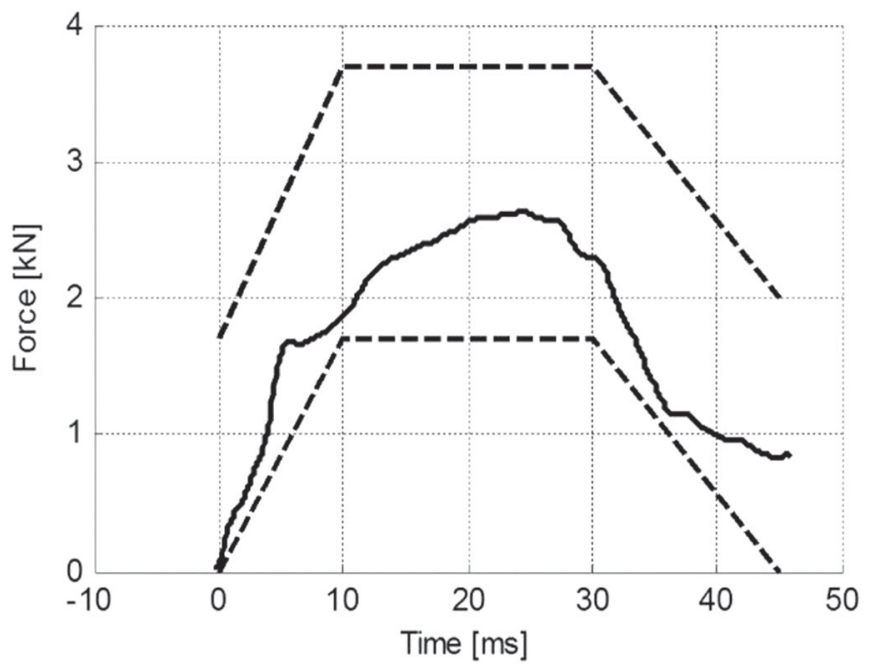

Obr. 7 Závislost kontaktní síly na čase při HSRI testu.

Fig. 7 Time history of the contact force in the HSRI test.

do hrudníku přibližně v úrovni 4 . hrudního obratle rychlostí $4,3 \mathrm{~m} / \mathrm{s}$ [5][6]. Validace je provedena na základě časového průběhu kontaktní síly mezi modelem a impaktorem. Model je umístěn do polohy vsedě se vzpaženými pažemi (viz obr. 6.). Z obr. 7, kde je zaznamenán výsledek testu, je zřejmé, že kontaktní síla zaznamenaná při simulaci vyhovuje př́slušnému koridoru.

Mimo výše zmíněných testů byl hrudník validován ještě pomocí testu s bezpečnostním pásem a šikmým nárazem [2].

\section{REKONSTRUKCE SRÁŽKY VOZIDLA S CHODCEM}

Ve standardním pre-procesoru - Visual Environment k explicitnímu řešiči VPS PAM-CRASH - byl vyvinut modul pro konfiguraci, 
simulaci a vyhodnocení čelní srážky vozidla s chodcem s konfigurovatelnými parametry. Je možné nadefinovat několik parametrů, které mohou ovlivňovat průběh a následky nehody a uzpůsobit tak scénář nehody specifickým požadavkům. Mezi konkrétní nastavitelné prvky patří: tvar přídě vozidla a rychlost jízdy, antropometrické parametry chodce, rychlost jeho chůze a jeho pozice vůči vozidlu v době nárazu.

\subsection{Typy modelů vozidel}

Simulace nehody může být provedena s různými modely vozidel uloženými v databázi. Z hlediska způsobu modelování jsou $\mathrm{v}$ databázi $\mathrm{k}$ dispozici tři typy vozidel:

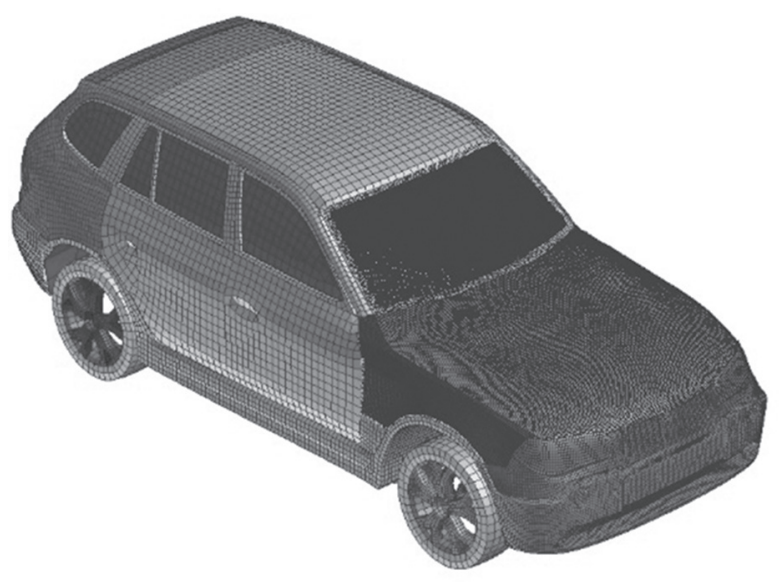

Obr. 8 Konečno-prvkový model vozidla Fig. 8 Finite element vehicle model

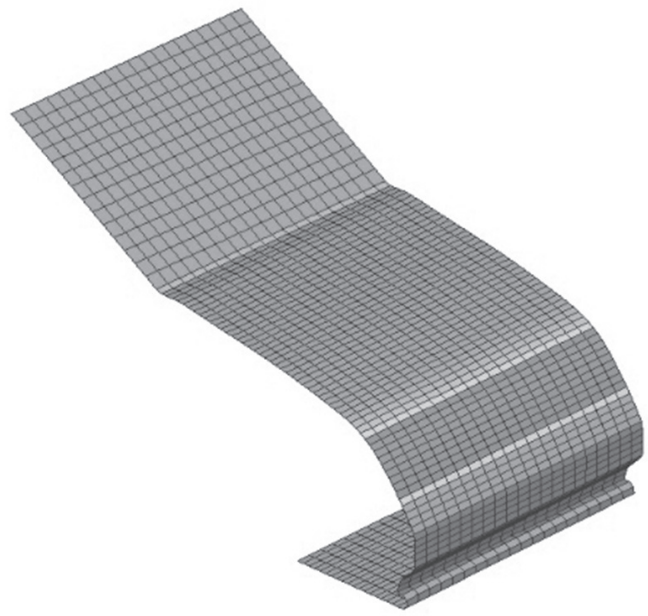

Obr. 9 MBS model vozidla

Fig. 9 MBS vehicle model

Konečno-prvkové modely s plně deformovatelnou přední částí (viz obr. 8). Tato vozidla jsou modelována detailně, s realistickými mechanickými a materiálovými vlastnostmi jednotlivých komponent.

MBS modely. Zjednodušené modely sestávající z tuhých dílů (kapoty, nárazníku a čelního skla) vzájemně propojených pásem deformovatelných prvků (viz obr. 9).

Kompletně tuhé modely. Geometrie těchto modelů je vytvořena detailně, ale celé vozidlo je tuhé, bez deformovatelných elementů.

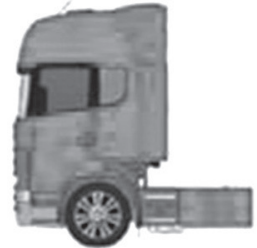

Trambus

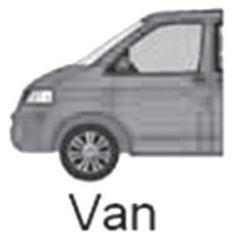

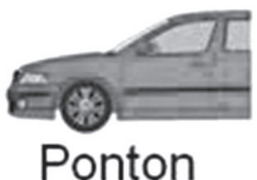

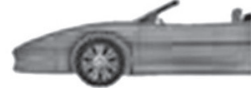

Wedge-shaped
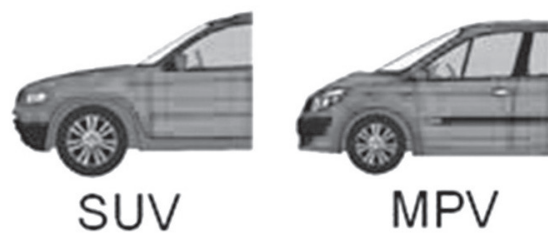

Obr. 10 Rozdělení vozidel podle tvaru př́dè.

Fig. 10 Types of vehicle according to the frontal end shape.

Vliv na průběh a následky nehody má tvar přední části vozidla. Podle jejího tvaru jsou vozidla v databázi rozdělena do šesti skupin zobrazených na obr. 10

\subsection{Vyhodnocení vybraných nehod s chodcem}

$\mathrm{V}$ rámci testování vlivu pozice hlavy chodce $\mathrm{v}$ okamžiku jejího kontaktu s vozidlem bylo provedeno několik simulací. Pro testování byli zvoleni dva jedinci - trrináctiletý chlapec $(150 \mathrm{~cm}, 40 \mathrm{~kg})$ a osmnáctiletý muž $(178 \mathrm{~cm}, 72 \mathrm{~kg})$. Oba byli umístěni před střed kapoty, levým bokem k automobilu, přičemž rychlost vozidla $\mathrm{v}$ době střetu byla uvažována $45 \mathrm{~km} / \mathrm{h}$. Konfigurace nehody je znázorněna na obr. 11 .
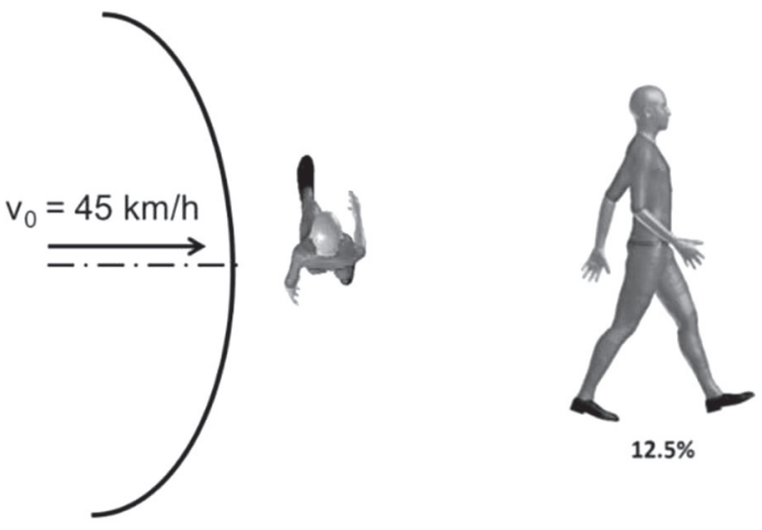

Obr. 11 Ilustrace pozice chodce před srážkou.

Fig. 11 Illustration of pedestrian positioning before the crash.

Vozidlo použité při těchto simulacích bylo reprezentováno plně deformovatelným (konečno-prvkovým) modelem rodinného vozu, jehož geometrie byla vytvořena na základě skenů povrchu reálného vozidla v rámci projektu TA04030689.

Vybrané časové kroky zachycující průběh srážky jsou zobrazeny na obr. 12 (trrináctiletý chodec) a obr. 13 (osmnáctiletý chodec). Zbarvení jednotlivých částí těla modelu chodce znázorňují závažnost předpokládaného poranění v daném časovém kroku - zelená značí poranění žádné nebo velmi mírné, žlutá mírné, oranžová vážné, červená fatální. 


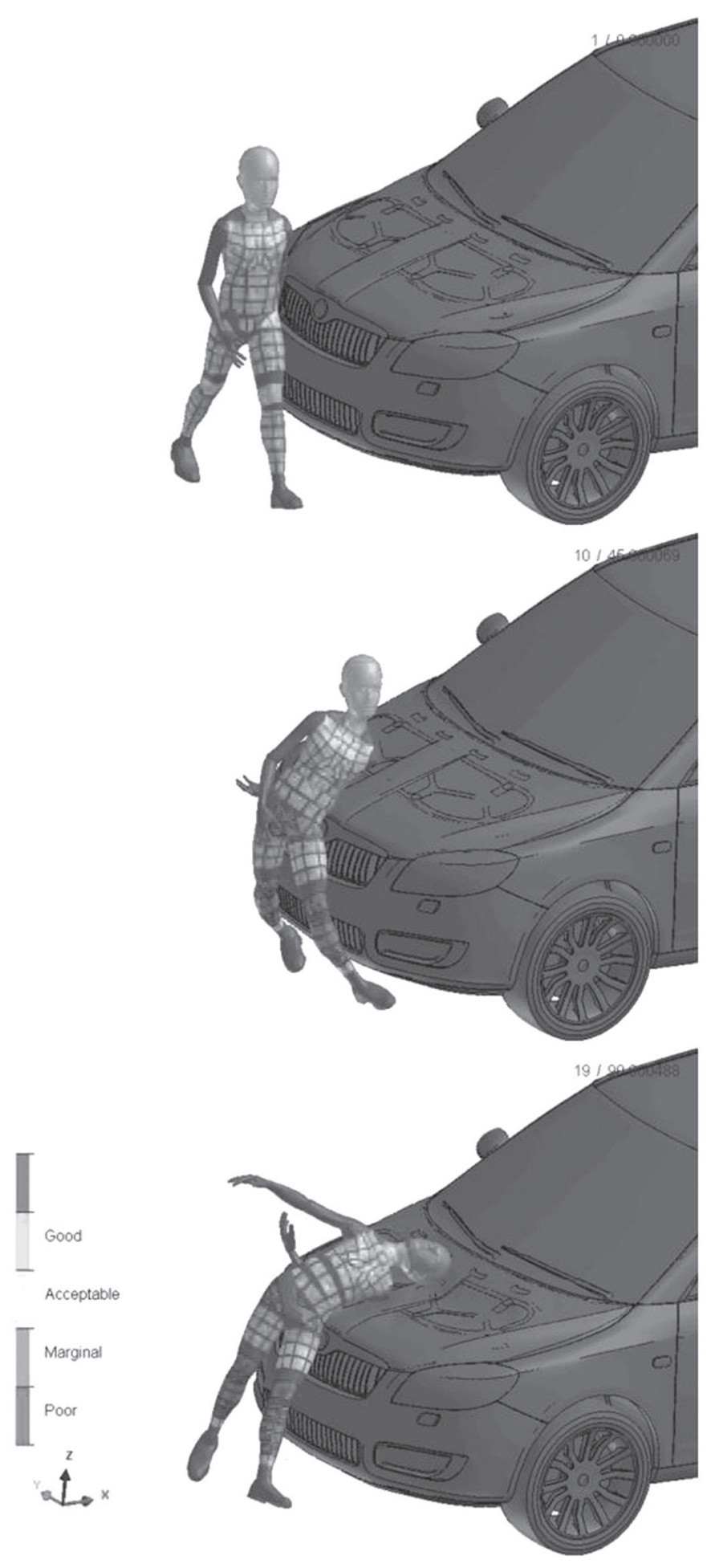

Obr. 12 Průběh srážky-chlapec, 13 let.

Fig. 12 Course of the crash-13 year-old.
V př́ipadě třináctiletého chlapce došlo v okamžiku prvního kontaktu $\mathrm{s}$ vozidlem $\mathrm{k}$ nárazu nárazníku do obou nohou, což předpovídá možné poranění kolen a lýtek. Poté dochází $\mathrm{k}$ nárazu pánve do přední hrany kapoty, kde s ohledem na červené zbarvení pánevní oblasti na druhém a třetím snímku lze předpovídat možnost vážného poranění. Trup i hlava poté dopadají na kapotu, přičemž hlava naráží do oblasti výztuhy, což vede k predikci vážného zranění hlavy.
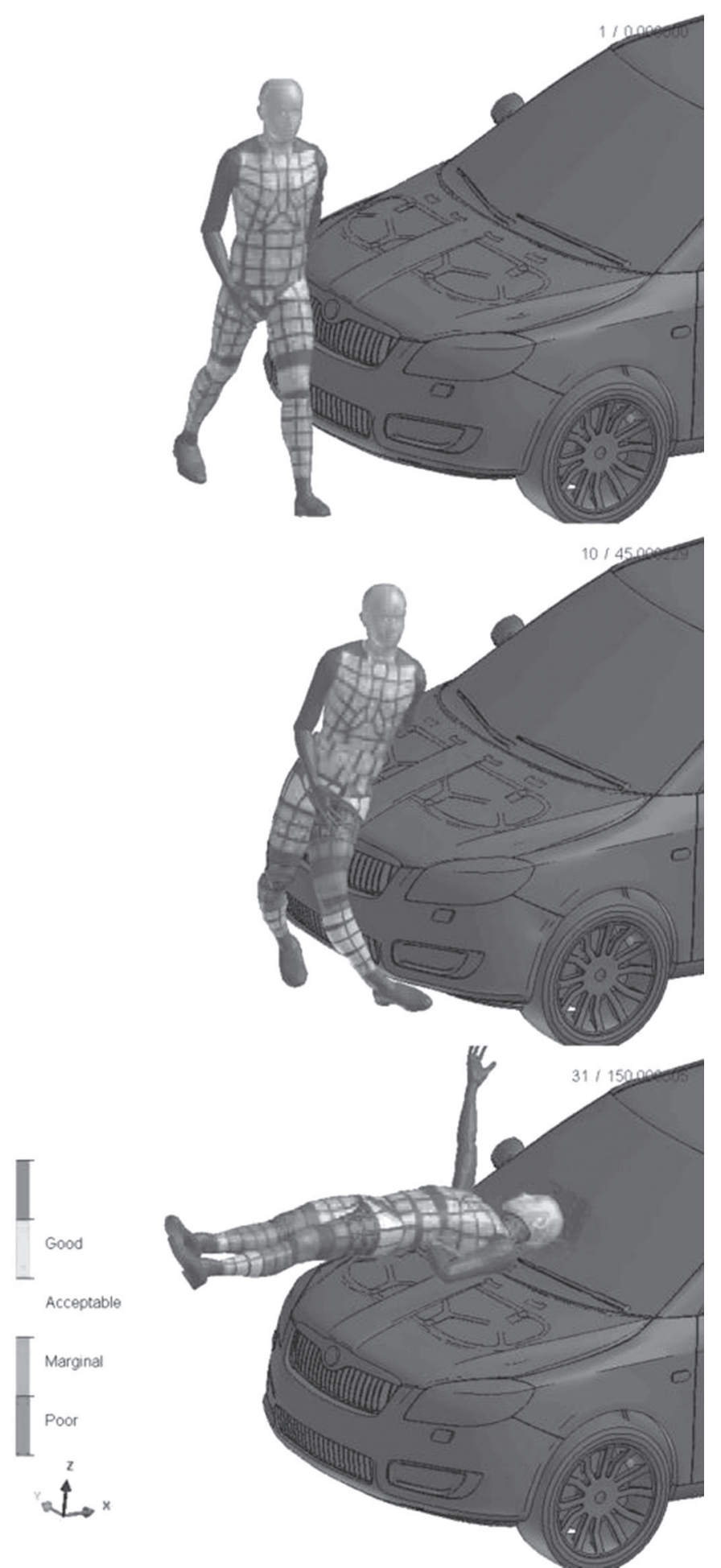

Obr. 13 Průběh srážky - muž, 18 let.

Fig. 13 Course of the crash - 18 year-old.

Průběh srážky s osmnáctiletým mužem je částečně odlišný. Při prvním kontaktu naráží nárazník do obou nohou. Na rozdíl od třináctiletého chlapce naráží přední hrana kapoty do levého stehna, jehož červené zbarvení na druhém snímku značí pravděpodobnost závažného poranění. Trup dopadá na kapotu, ale hlava v tomto př́padě naráží až do čelního skla. Tento scénář nepředpovídá žádné vážné poranění hlavy, nicméně dopad hlavy 
vyvolá značné síly působící na oblast krku, což vede k předpovědi jeho závažného poranění.

\section{ZÁV̌̌R}

Prezentovaný virtuální model lidského těla VIRTHUMAN je plně validovaný, což umožňuje jeho využití ve virtuálním testování bezpečnostních prvků vozidel a jiných aplikacích, nejen v oblasti dopravy. Zvolený hybridní př́stup k modelování umožňuje připravit a vyhodnotit simulace $\mathrm{v}$ relativně krátkém čase ve srovnání s plně deformovatelnými modely lidského těla. Současně je díky deformovatelným elementům zachována realistická odezva jednotlivých částí těla.

Nástroj vyvinutý pro simulaci srážek vozidla s chodcem společně s modelem VIRTHUMAN může být využit pro testování bezpečnostních systémů, nebot' dokáže predikovat průběh a následky různě konfigurovaných dopravních nehod. Lze například sestavit požadovaný scénář nehody a postupně pak měnit některý z parametrů, jakým může být výška chodce nebo jeho natočení vůči vozidlu a sledovat vliv těchto parametrů při stanovení bezpečnosti konstrukce přední části vozu. Velmi užitečný může tento nástroj být i při rekonstrukci reálných dopravních nehod.

\section{LITERATURA}

[1] BESIP: Dopravní nehodovost v roce 2015 - Chodci, Ministerstvo dopravy, Praha, 2016. Dostupné z (01/09/2018): http://www. ibesip.cz/cz/statistiky/statistiky-nehodovosti-v-ceske-republice/ dopravni-nehodovost-v-roce-2015/chodci

[2] VYCHYTIL, J., MAŇAS, J., ČECHOVÁ, H., ŠPIRK, S., HYNČÍK, L., KOVÁŘ, L. Scalable Multi-Purpose Virtual Human Model for Future Safety Assessment, SAE Technical Paper 2014-01-0534, 2014, doi:10.4271/2014-01-0534.

[3] KROELL, Ch. K., SCHNEIDER, D. C., NAHUM, A. M. Impact Tolerance and Response of the Human Thorax, SAE Technical Paper 710851, 1971, doi:10.4271/710851.

[4] KROELL, Ch. K., SCHNEIDER, D. C., NAHUM, A. M.: Impact Tolerance and Response of the Human Thorax II, SAE Technical Paper 741187, 1974, doi:10.4271/741187.

[5] SHAW, J. M., HERRIOTT, RODNEY G., McFADDEN, J. D., DONNELLY, B. R., BOLTE, J. H. Oblique and Lateral Impact Response of the PMHS Thorax. Stapp Car Crash Journal, 50, s. 147-167, 2006.

[6] JANSOVÁ, M., TOCZYSKI, J. Report on the result of the comparison of the model against corridors. Thomo project deliverable - Development of a Finite Element Model of the Human Thorax and Upper Extremities, No. D3.1., 2011.

\section{Správná citace:}

Kovář, L., Hluchá, J., Novotný, T. Analýza průběhu dopravních nehod s virtuálním modelem člověka VIRTHUMAN. Soudní inženýrství, 2018, 29(3), 7-12. ISSN 1211-443X. 